\title{
Simultaneous determination of cereal monosaccharides, xylo- and arabinoxylo- oligosaccharides and uronic acids using HPAEC-PAD
}

\author{
Alyassin $\mathrm{M}^{\mathrm{a}}$, Campbell GM${ }^{\mathrm{a}}$, Masey O’Neill $\mathrm{H}^{\mathrm{b}}$ and Bedford $\mathrm{MR}^{\mathrm{c}}$
}

a. School of Applied Sciences, University of Huddersfield, Queensgate, Huddersfield, UK

b. AB Agri Ltd., 64 Innovation Way, Peterborough Business Park, Lynch Wood, Peterborough, PE2 6FL, UK

c. AB Vista Ltd., Woodstock Court, Blenheim Road, Marlborough, UK

* Author for correspondence, M.Alyassin2@hud.ac.uk

10

\section{Highlights}

- The simultaneous determination of mono and oligosaccharides using HPAEC

- The validation of the presented HPAEC method

- Screening the released oligosaccharides released from wheat bran with endoxylanase

- The activity of commercial xylanase on oligosaccharides standards X5 and X6

- The studied xylanase showed a preference

\section{Abstract}

Xylo- and arabinoxylo-oligosaccharides (XOS and AXOS) are of interest for their prebiotic activity. The production of these oligomers might be accompanied with monosaccharides. The measurement of both oligosaccharides and monosaccharides usually requires two methods. The current work presents an HPAEC-PAD method based on gradient elution of aqueous solvents sodium hydroxide and sodium acetate, in contrast to conventional isocratic elution, for the simultaneous separation of 16 standards of monosaccharides, xylooligosaccharides, arabinoxylo-oligosaccharides and uronic acids using CarboPac PA 200 column. The presented method showed a stable baseline and high-resolution separation of the standards. The method showed acceptable accuracy and precision. Limits of Detection and Quantitation (LOD and LOQ) were estimated for all the standards. The method was applied to measure the activity of a commercial endoxylanase on wheat bran; a steady release of 
30 xylose monosaccharide was observed. Enzyme action on oligosaccharide standards showed a 31 preference for the larger oligosaccharides.

\section{Keywords}

33 Arabinoxylo-oligosaccharides (AXOS), xylo-oligosaccharides (XOS), HPAEC-PAD, 34 xylanase activity, oligosaccharide separation, wheat bran 


\section{1-Introduction}

Arabinoxylans $(\mathrm{AX})$ are an abundant non-starch polysaccharide that occurs in the outerlayers and endosperm cell walls of cereals grains, associated with cellulose and lignin to provide the structural framework of the grain (Biliaderis et al., 1995; Vinkx and Delcour, 1996). AX consist of a linear chain of $\beta$-D-xylopyranosyl with $\alpha$-L-arabinofuranoside residues attached to the xylose units at O-3, O-2 and/or both O-2, 3 positions (Izydorczyk and Dexter, 2008; Saulnier et al., 2007). The breakdown of AX polymers to arabinoxylanoligosaccharides (AXOS) and the linear xylo-oligosaccharides (XOS) has become of interest due to the impact of these oligomers on human and animal health via prebiotic activity. AXOS and XOS are fermented by Bifidobacterium strains to produce metabolically active compounds such as short chain fatty acids, thus invigorating the activity of the gut bacteria and improving gut health, reducing infections and suppressing colon cancer (Van Craeyveld et al., 2008; Broekaert et al., 2011; Immerzeel et al., 2014). Increasing consumption of these prebiotics could enhance human and animal nutrition. Xylanases are already used in bread formulations to improve dough rheological properties by hydrolysing large AX molecules, leading to some production of AXOS; judicious use of enzymes to enhance this AXOS production while retaining good dough handling properties could increase AXOS consumption in human diets (Damen et al., 2012). Similarly, xylanases are traditionally added to animal feed in order to reduce the viscosity of the feed in the animal digestion system, but recent research has highlighted the additional prebiotic benefits arising from XOS and AXOS, and attention is now focussed on understanding and exploiting these prebiotics in animal feed formulations (González-Ortiz et al., 2019).

Because of its interest as a prebiotic material, there have been a number of studies investigating production of XOS from a range of substrates. Most research to date has focussed on XOS rather than AXOS, the latter being harder to analyse due to the lack, until 
60 recently, of readily available standards. Table 1 illustrates the range of materials,

61 pretreatments and enzyme combinations that have been investigated and the resulting yields

62 of XOS. Bagasse, corncobs and the various components of wheat have been of interest as

63 they naturally arise within biorefineries and offer a ready feedstock for further co-product

64 production, while birchwood, tobacco stalks and cotton stalks have also been investigated.

65 Pretreatments have included steam explosion, alkaline and acidic extraction, and ultrasound.

66 Other enzymes have been deployed alongside endoxylanases: feruloyl esterases to aid release

67 of AX by breaking ferulic acid crosslinks; arabinofuranosidases to shave off the arabinose

68 units; and cellulases, glucosidases and xylosidases to help break down the structure to release

69 AX. Yields have varied according to substrate, pretreatment and enzymes, with the highest

70 yields from purified birchwood xylan following endoxylanase treatment (Falck et al., 2013;

71 Nieto-Domínguez et al., 2017) and from Kenaf stems (Wan Azelee et al., 2016). 
Table 1. Yields of XOS from various biomass substrate and enzyme combinations reported in the

literature.

\begin{tabular}{|c|c|c|c|c|}
\hline Biomass & Pre-treatment & Enzymes & $\begin{array}{c}\text { Yields of XOS } \\
\text { from original } \\
\text { material* }\end{array}$ & Reference \\
\hline Sugarcane bagasse & $\begin{array}{l}\text { Aqueous } \\
\text { ammonia }\end{array}$ & $\begin{array}{c}\text { Bacterial } \\
\text { arabinofuranosidase } \\
+\beta \text {-xylosidase }\end{array}$ & $*$ & $\begin{array}{c}\text { (Reddy and } \\
\text { Krishnan, 2016) }\end{array}$ \\
\hline Sugarcane bagasse & $\begin{array}{l}\text { Alkaline } \\
\text { extraction }\end{array}$ & $\begin{array}{c}\text { Bacterial cellulase }+ \\
\text { endoxylanase }\end{array}$ & $6 \%$ & (Xue et al., 2016) \\
\hline Wheat bran & Destarching & $\begin{array}{c}\text { Fungal endoxylanase } \\
+ \\
\text { Feruloyl esterase }\end{array}$ & $* *$ & (Wu et al., 2017) \\
\hline Wheat chaff & Ultrasound & Endoxylanase & $\begin{array}{c}8 \%(+2-3 \% \\
\text { xylose }) \\
\end{array}$ & $\begin{array}{c}\text { (Antov and } \\
\text { Đorđević, 2017) }\end{array}$ \\
\hline Wheat straw & $\begin{array}{l}\text { Alkaline } \\
\text { extraction }\end{array}$ & $\begin{array}{c}\text { Bacterial } \\
\text { endoxylanase }\end{array}$ & $11 \%$ & (Faryar et al., 2015) \\
\hline Wheat straw & $\begin{array}{l}\text { Steam } \\
\text { explosion }\end{array}$ & $\begin{array}{c}\text { Commercial } \\
\text { endoxylanase + } \\
\text { glucosidase }\end{array}$ & $8.9 \%$ & $\begin{array}{c}\text { (Álvarez et al., } \\
\text { 2017) }\end{array}$ \\
\hline Birchwood & - & $\begin{array}{l}\text { Fungal endoxylanase } \\
\text { GH11 }\end{array}$ & $28.8 \%$ & $\begin{array}{l}\text { (Nieto-Domínguez } \\
\text { et al., 2017) }\end{array}$ \\
\hline Birchwood, Rye & - & $\begin{array}{c}\text { Bacterial } \\
\text { endoxylanase }\end{array}$ & $\begin{array}{c}20 \% \text { birchwood } \\
3.3 \% \text { rye }\end{array}$ & (Falck et al., 2013) \\
\hline $\begin{array}{l}\text { Kenaf stems } \\
\text { (Hibiscus } \\
\text { cannabinus) }\end{array}$ & $\begin{array}{c}\mathrm{Ca}(\mathrm{OH})_{2} \\
\text { followed by } \\
\text { peracetic acid }\end{array}$ & $\begin{array}{l}\text { endoxylanase and } \\
\text { arabinofuranosidase }\end{array}$ & $35.2 \%$ & $\begin{array}{c}\text { (Wan Azelee et al., } \\
\text { 2016) }\end{array}$ \\
\hline Corncob & $\begin{array}{c}\text { Alkaline } \\
\text { extraction }\end{array}$ & Bacterial xylanase & $* *$ & $\begin{array}{l}\text { (Gowdhaman and } \\
\text { Ponnusami, 2015) }\end{array}$ \\
\hline Corncob & $\begin{array}{l}\text { Alkaline } \\
\text { extraction }\end{array}$ & Fungal $\beta$-xylosidase & $10.7 \%$ & (Chapla et al., 2012) \\
\hline Corncob & $\begin{array}{c}\text { Acidic } \\
\text { hydrolysis }\end{array}$ & Cellulase & $\begin{array}{c}14 \% \\
(+32.8 \% \text { glucose } \\
14.8 \% \text { xylose })\end{array}$ & (Zhang et al., 2017) \\
\hline Corncob & $\begin{array}{l}\text { Hydrothermal } \\
+16 \% \text { alkali } \\
\end{array}$ & $\begin{array}{c}\text { Commercial } \\
\text { endoxylanase }\end{array}$ & $9 \%$ & $\begin{array}{c}\text { (Samanta et al., } \\
\text { 2015) }\end{array}$ \\
\hline Corncob & $\begin{array}{l}\text { Alkali/acid } \\
\text { pressure } \\
\text { cooking }\end{array}$ & Fungal endoxylanase & $* *$ & $\begin{array}{l}\text { (Aachary and } \\
\text { Prapulla, 2009) }\end{array}$ \\
\hline Tobacco stalk & $\begin{array}{l}\text { Alkaline } \\
\text { extraction }\end{array}$ & $\begin{array}{l}\text { Commercial } \\
\text { endoxylanase }\end{array}$ & $11 \%$ & $\begin{array}{c}\text { (Akpinar et al., } \\
\text { 2010) }\end{array}$ \\
\hline Cotton stalk & $\begin{array}{l}\text { Alkaline } \\
\text { extraction }\end{array}$ & $\begin{array}{l}\text { Commercial fungal } \\
\text { endoxylanase }\end{array}$ & $10.6 \%$ & $\begin{array}{c}\text { (Akpinar } \text { et al., } \\
\text { 2007) }\end{array}$ \\
\hline
\end{tabular}

* Yields are measured and reported in a variety of ways and with varying precision, and are indicative rather than directly comparable.

$77 \quad * * \quad$ Insufficient data 
79 Studies of enzymatic XOS production have only occasionally reported the accompanying release of monosaccharides. Uçkun Kiran et al. (2013) reported that two commercial endoxylanases released different amounts of undesired xylose monosaccharide in the extracts. Antov and Dorđević (Antov and Đorđević, 2017) advised that the endoxylanase treatment time is crucial to minimise the production of monosaccharides.

Generally, the activity of endoxylanases on oligosaccharides is not well understood. For example, only a limited number of contradictory reports in the literature discuss whether endoxylanases produce monosaccharides or not (Antov and Đorđević, 2017; Cürten et al., 2018; Uçkun Kiran et al., 2013). Also, the action or preference of endoxylanases for larger or smaller oligosaccharides chains has not previously been reported, as the interest in the hydrolysing enzymes has been primarily their efficacy in breaking down the polysaccharides either all the way to the constituent monosaccharides (as a fermentation feedstock, for example) or just to reduce viscosity. Now, with the increasing interest in oligosaccharides arising from their prebiotic functionality, it has become essential to investigate in detail the mode of action of xylanases on the production and degradation of small xylo- and arabinooligosaccharides. However, such investigations faced the difficult technical challenges of measuring these oligosaccharides.

High performance anion exchange chromatography with pulsed amperometric detection (HPAEC-PAD) has been the method of choice for carbohydrate analysis (Cui and Brummer, 2005). The utilisation of PAD enables a sensitive detection, which is indispensable in the case of complex samples. Recently, the commercial availability of XOS standards up to DP6 and a smaller number of AXOS standards has facilitated the separation of these analytes in a simple and direct analysis using an HPAEC-PAD system. The accurate determination of xylanase activity by directly measuring the produced oligosaccharides has thus become a routine analysis. Falck et al. (2015) determined the XOS and AXOS produced by different xylanases 
using an HPAEC system with a CarboPac PA200 column and a fixed $100 \mathrm{mM}$ sodium hydroxide aqueous solution with a linear increase of sodium acetate from 0 to $120 \mathrm{mM}$ within a 30-minute run. Cürten et al. (2018) reported a faster method for the analysis of XOS using a CarboPac PA100 column with a more concentrated mobile phase composition. Other reports have showed the effective usage of HPAEC-PAD for the quantification of XOS and/or AXOS variously using CarboPac columns PA1, PA100 and PA200 to measure XOS in the range DP2-6 (Arruda et al., 2017; Bian et al., 2013, 2014; Courtin et al., 2009; Gullón et al., 2008; Lafond et al., 2011; Li et al., 2013; Zhang et al., 2017). All of these used a fixed (isocratic) concentration of sodium hydroxide, with gradient elution of sodium acetate, in varying proportions and molarities.

The fast and reliable analysis together with the availability of standards have made this technique the favoured choice for oligosaccharides analysis. However, the isocratic elution of sodium hydroxide solution, as recommended by the manufacturers (Dionex Corporation, 2004), severely reduces the resolution of the monosaccharides and to some extent the oligosaccharides; these recommendations are probably inherited from the first generations of ion exchange techniques when RI detectors were the only option. With isocratic elution, the analysis of monosaccharides requires different conditions from those for oligosaccharides; hence, to get the full picture of enzyme hydrolysis activity, samples need to be analysed twice under different conditions and with two different columns and mobile phases, to quantify the monosaccharides and the oligosaccharides separately (Mathew et al., 2017). Furthermore, the content of the uronic acids (glucuronic and galacturonic acid, which are prevalent in wheatderived $\mathrm{AX}$ ) has not been considered in conjunction with oligosaccharide analysis in the literature, as it has also required different conditions. Due to these various technical limitations, the precise activity of xylanases in terms of their activity on oligosaccharides has not been well described in the literature. 
129 Therefore, the current work introduces the use of gradient elution of both sodium hydroxide

130 and sodium acetate to give a high resolution method for the simultaneous determination of

131 cereal monosaccharides (arabinose, galactose, glucose and xylose), along with xylo-

132 oligosaccharides in the range DP2-6, and arabinoxylo-oligosaccharides $\left(2^{3}-\alpha-\mathrm{L}-\right.$

133 arabinofuranosyl-xylotriose (A2XXX), $3^{3}$ - $\alpha$-L-arabinofuranosyl-xylotetraose (XA3XXX), $2^{3}$ -

$134 \alpha$-L-arabinofuranosyl-xylotetraose (XA2XXX) and $2^{3}, 3^{3}$-di- $\alpha$-L-arabinofuranosyl-xylotriose

135 (A2A3XXX)), as well as the uronic acids (glucuronic and galacturonic acid). The method

136 allows a comprehensive description, quantitative and qualitative, of the modes of action of

137 xylan-degrading enzymes as well as the substrate specificity of the enzymes.

138 This paper describes the materials and instrument used, then evaluates the performance of the

139 method in terms of validation and system suitability parameters. The method is then applied

140 to follow the sugars released from wheat bran following treatment with a commercial

141 endoxylanase. The method is further illustrated in a selected result from a study of the

142 endoxylanase activity on small oligosaccharide standards, in which the evolving

143 oligosaccharide profile was followed as a function of the relative preference of the enzyme

144 for different sizes of oligosaccharide substrate.

\section{2- Materials and Methods}

146 2.1- Materials

147 Standards of monosaccharides fucose (as internal standard), arabinose, galactose, glucose and 148 xylose were obtained from Sigma UK. Xylan oligosaccharides (arabinose, galactose, glucose 149 and xylose), xylo-oligosaccharides (xylobiose (X2), xylotriose (X3), xylotetraose (X4), 150 xylopentaose (X5) and xylohexaose (X6)) and arabinoxylo-oligosaccharides ( $2^{3}-\alpha$-Larabinofuranosyl-xylotriose (A2XXX), $3^{3}$ - $\alpha$-L-arabinofuranosyl-xylotetraose (XA3XXX), $2^{3}$ $\alpha$-L-arabinofuranosyl-xylotetraose (XA2XXX) and $2^{3}, 3^{3}$-di- $\alpha$-L-arabinofuranosyl-xylotriose (A2A3XXX)) were purchased from Megazyme (Bray, Ireland). Glucuronic acid, 
154 galacturonic acid, sodium acetate, sodium hydroxide (52\%), citric acid and sodium phosphate mono-basic were obtained from Fisher scientific UK. Commercial xylanase Econase XT 25L (160.000 BXU/g) was supplied by AB Vista (Marlborough, UK). Wheat bran was kindly provided by Biorenewables Development Centre, York, UK.

\section{2- Chromatography System}

The HPAEC-PAD system used was a Dionex ICS-3000 Ion Chromatography System with gold electrode (Dionex Corporation, CA, USA) consisted of an ICS-3000 dual pump, an AS50 autosampler and an ICS-3000 DC (Detector/Chromatography) compartment with an electrochemical detector with a gold working electrode, an $\mathrm{Ag} / \mathrm{AgCl}$ reference electrode. The separation was performed on a CarboPac PA200 (3 $\mathrm{mm} \times 250 \mathrm{~mm})$ with a CarboPac PA200 guard $(3 \mathrm{~mm} \times 50 \mathrm{~mm})$ column and a CarboPac PA20 $(3 \mathrm{~mm} \times 150 \mathrm{~mm})$ with a CarboPac PA20 guard $(3 \mathrm{~mm} \times 30 \mathrm{~mm})$ column. Chromeleon ${ }^{\circledR}(6.8)$ software was utilised for data processing.

\section{3- Chromatographic conditions}

Gradient elution of two mobile phases was performed: Solution A comprising $10 \mathrm{mM}$ sodium hydroxide; and Solution B comprising a mixture of $200 \mathrm{mM}$ sodium hydroxide and $125 \mathrm{mM}$ sodium acetate. The elution was performed starting with $100 \%$ Solution A at time 0 with a linear increase of Solution B to reach $100 \%$ after thirty minutes, then held at $100 \%$ B for five minutes (Alyassin, 2019). Column equilibration was performed by maintaining starting conditions $(100 \%$ A) for at least 15 min before sample injection. The mobile phase was sparged with helium and kept under helium during the analysis. The elution flow rate was maintained at $0.3 \mathrm{~mL} \min ^{-1}$ and the injection volume was $20 \mu \mathrm{L}$. Pulsed wave form "carbohydrates (standard quad)", wave form description "carbohydrates (std. quad. Potential)" was used for the detection. Fucose was used as an internal standard. 


\section{4- Preparation of standard solutions}

A primary stock solution of each standard was prepared in Milli-Q $(18.2 \mathrm{M} \Omega \mathrm{cm})$ water to obtain a concentration of $2 \mathrm{mg} \mathrm{mL} \mathrm{mL}^{-1}$. Then a secondary stock solution of a mixture of all the standards was prepared at concentrations of $100 \mathrm{mg} \mathrm{L}^{-1}$ each. Serial dilutions with water were performed to prepare the calibration curve for each standard. The concentration range for working standard solutions was $1-20 \mathrm{mg} \mathrm{L}^{-1}$. The standards solution was found to be stable when kept refrigerated at $4^{\circ} \mathrm{C}$.

\section{5- Xylanase action on wheat bran}

Wheat bran was washed with water at $70^{\circ} \mathrm{C}$ with continuous stirring for 60 minutes, then strained over a 250-micron sieve three times to ensure the removal of any residual starch. The washed bran was oven-dried overnight at $75^{\circ} \mathrm{C}$.

A sample of $20.0 \mathrm{~g}$ of the washed dried bran was weighed into a flask with $200 \mathrm{~mL}$ of citrate/ phosphate buffer at $\mathrm{pH} 4.5$ and placed in a shaking water bath at $50^{\circ} \mathrm{C}$. One $\mathrm{mL}$ of the enzyme was added equivalent to $50 \mathrm{~mL}$ per $\mathrm{kg}$ of dry sample or $500 \times$ the commercial dosage, to accelerate changes, after which $10 \mathrm{~mL}$ samples of the solution were taken after $0,30,60$ and 120 minutes and submerged in an ice bath to halt the enzyme activity. The samples were diluted and filtered over 0.45-micron syringe filters and analysed in the HPAEC system. Samples were injected manually directly after removal from the ice bath, thus samples remained cold such that enzyme activity did not resume prior to analysis.

\section{6- Enzymatic degradation of XOS standards}

Solutions containing a mixture of xylohexaose and xylopentaose standards at $100 \mathrm{mg} \mathrm{L}^{-1}$ each were incubated with the endoxylanase in $\mathrm{pH} 4.5$ phosphate/citrate buffer in a water bath at $50^{\circ} \mathrm{C}$. The enzyme was added at a dosage of $50 \mathrm{~mL}$ per $\mathrm{kg}$ of dry sample. Samples were 
201

202

203

204

205

206

207

208

209

210

211

212

213

214

215

216

217

taken at 10, 20, 40, 60 and 120 minutes, to evaluate the XOS production and degradation over time. The samples were diluted using phosphate-citrate buffer (at $\mathrm{pH}$ 7) and boiled for 20 minutes to deactivate the enzyme permanently to allow queuing in the autosampler without further enzyme activity, then kept at room temperature until analysis.

\section{3- Results and discussion}

\section{1- Chromatography and specificity}

Figure 1(a) shows a chromatogram of the standards mixture of the studied analytes, each at a concentration of $20 \mathrm{mg} \mathrm{mL}$, obtained using the CarboPac PA200 column. The chromatographic run time of 35 minutes was sufficient for the elution of all standards. The baseline was smooth and stable in all the analysed samples, and the gradient elution gave a high resolution separation and did not affect the baseline. In fact, the linear gradient elution of the alkaline aqueous solvent not only enhanced the separation of oligosaccharides, it also increased the capability of the columns used for the separation. The CarboPac PA20 is commercialised as the column of choice for mono- and disaccharides, but with the applied conditions the PA20 was also able to separate the oligosaccharides efficiently although over a longer time, as illustrated in Figure 1(b). The PA200 was used for the remainder of the current work as it allowed faster run times. 


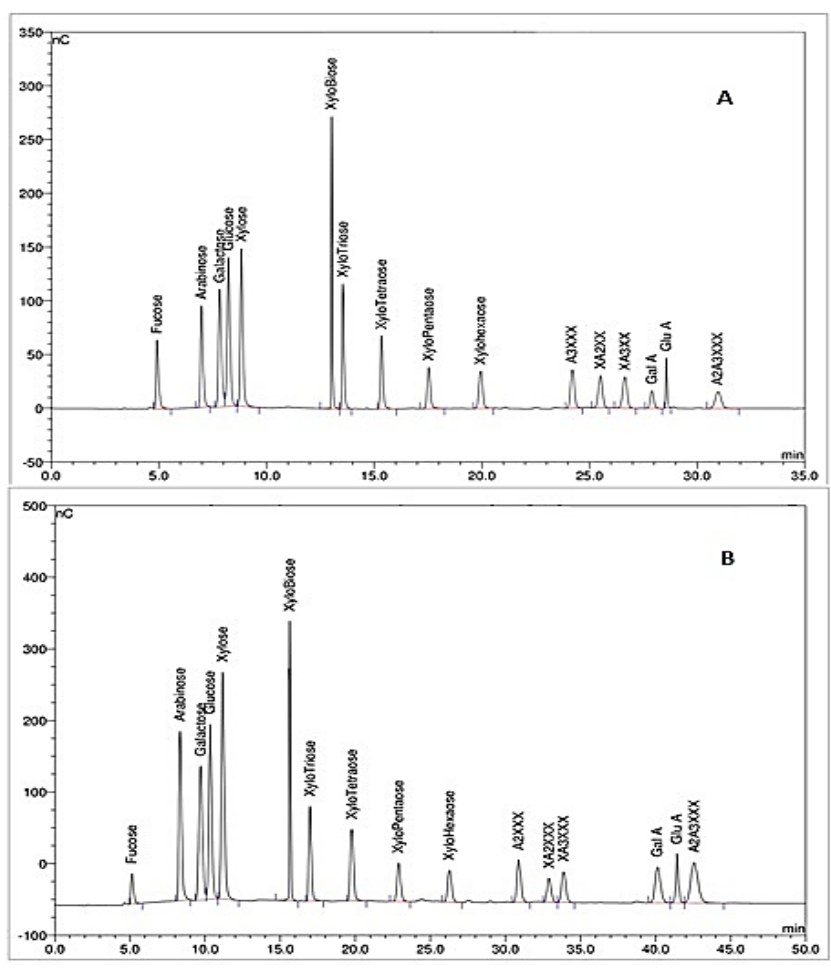

Figure 1 Chromatogram of mono and oligo saccharides mixture using (a) CarboPac PA200, and (b)

CarboPac PA20.

\section{2- Linearity}

224 To assess linearity, calibration curves were plotted using the ratio of the analyte peak area to

225 the internal standard peak area against concentrations of different dilutions $(n=9)$ covering 226 the range 1-100 $\mathrm{mg} \mathrm{mL}^{-1}$ for monosaccharides and 1-20 $\mathrm{mg} \mathrm{mL}^{-1}$ for XOS, AXOS and uronic 227 acids. The correlation coefficient values were acceptable for all the standards and ranged 228 between 0.985 and 0.999 . The correlation coefficients $\left(\mathrm{R}^{2}\right)$ are reported in Table 2, along with 229 Limits of Detection (LOD) and Quantitation (LOQ). 
Table 2. The HPAEC method linearity, $L O D, L O Q$, resolution, and separation efficiency parameters for the studied monosaccharides, oligosaccharides and uronic acids.

\begin{tabular}{|c|c|c|c|c|c|c|c|}
\hline & $\mathrm{R}^{2}$ & LOD $\mathrm{mg} \mathrm{L}^{-1}$ & LOQ mg L ${ }^{-1}$ & $\begin{array}{l}\text { Resolution } \\
\text { factor } R_{s}\end{array}$ & $\begin{array}{c}\text { Asymmetry } \\
A_{s}\end{array}$ & $\begin{array}{l}\text { Capacity } \\
\text { factor } k^{\prime}\end{array}$ & $\begin{array}{c}\text { Theoretical } \\
\text { plates }\end{array}$ \\
\hline Arabinose & 0.999 & 0.03 & 0.08 & 3.63 & 1.35 & 2.676 & 17620 \\
\hline Galactose & 0.996 & 0.08 & 0.1 & 1.71 & 1.1 & 3.114 & 15701 \\
\hline Glucose & 0.996 & 0.08 & 0.1 & 2.64 & 1.08 & 3.334 & 18981 \\
\hline Xylose & 0.997 & 0.04 & 0.1 & 10.23 & 1.26 & 3.649 & 26455 \\
\hline Xylobiose & 0.984 & 0.001 & 0.008 & 26.6 & 1.1 & 5.851 & 1081600 \\
\hline Xylotriose & 0.983 & 0.05 & 0.1 & 9.46 & 1.23 & 6.132 & 112710 \\
\hline Xylotetraose & 0.981 & 0.2 & 0.4 & 9.15 & 1.33 & 7.071 & 80127 \\
\hline Xylopentaose & 0.985 & 0.3 & 0.5 & 8.25 & 1.09 & 8.228 & 69836 \\
\hline Xylohexaose & 0.986 & 0.03 & 0.1 & 13.27 & 1.04 & 9.5 & 61511 \\
\hline $\mathrm{A} 3 \mathrm{XXX}$ & 0.994 & 0.04 & 0.08 & 3.91 & 1.1 & 11.737 & 91312 \\
\hline XA2XXX & 0.993 & 0.01 & 0.03 & 3.13 & 0.95 & 12.43 & 82712 \\
\hline XA3XXX & 0.990 & 0.01 & 0.03 & 3.69 & 0.95 & 13.026 & 82668 \\
\hline A2A3XXX & 0.995 & 0.08 & 0.2 & 23.52 & 1.05 & 15.298 & 57549 \\
\hline Gal A & 0.984 & 0.06 & 0.2 & 3.06 & 1.07 & 13.684 & 130671 \\
\hline Glu A & 0.997 & 0.06 & 0.1 & 7.47 & 1.37 & 14.035 & 793131 \\
\hline
\end{tabular}

\section{3- Limits of detection (LOD) and quantitation (LOQ)}

LOD and LOQ measure analytical method sensitivity to low concentrations of analyte. LOD

is the lowest concentration detected and LOQ is the minimum quantifiable concentration measured by the method (Uhrovčík, 2014). Signal-to-noise (S/N) ratios of 3:1 and 10:1 were used to define LOD and LOQ, respectively, and were calculated by the Chromeleon ${ }^{\circledR}$ software. The peaks were clear to identify after the dilutions and had acceptable precision. LOD and LOQ values for all the analytes are listed in Table 2. The table shows variation in

242 the detection and quantification limits of the standards, which is a reflection of the variation 243 in the peak heights and areas for the same concentrations, as evident in Figure 1. In general 244 the monosaccharides showed lower detectable concentrations than the oligosaccharides, except for xylobiose which is more readily detected than xylose and gave the lowest values of 
subject to the fitness of the of the PAD; in other words, the gradual recession of the gold

248 electrode (electrode fouling) can cause loss of detector signal over time, which requires

249 regular cleaning of the gold electrode.

\section{$250 \quad 3.4-$ Accuracy and precision}

251 The accuracy of the method was studied by analysing triplicates of control samples covering 252 three concentration levels $(5,10,15 \mathrm{ppm})$; the results are listed in Table 3 as percentage 253 recovery. The calculated recoveries for all the studied standards ranged acceptably between $25497-103 \%$. The precision of a method reflects the agreement among individual test results. 255 Intra-day precision (repeatability) was estimated by analysing seven replicates of a control 256 sample in the same run. Inter-day precision (intermediate precision) was assessed from nine 257 triplicates over three consecutive days (three runs per day) using the same instrument with 258 different batches of the mobile phase. Both repeatability and intermediate precision results 259 are listed in Table 3 as the percentage coefficient of variation (CV \%). Both the precision and 260 the intermediate precision are in acceptable ranges for all the analytes. 
Table 3. Method accuracy (reported as percentage recovery) and precision (reported as CV\%).

\begin{tabular}{|c|c|c|c|c|c|c|c|c|c|c|c|c|c|c|c|c|}
\hline \multirow{2}{*}{ 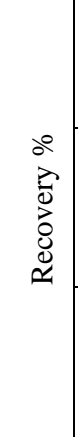 } & $15 \mathrm{ppm}$ & $\begin{array}{c}101.02 \pm \\
0.64\end{array}$ & $\begin{array}{c}100.46 \pm \\
1.46\end{array}$ & $\begin{array}{c}100.28 \pm \\
0.82\end{array}$ & $\begin{array}{c}100.42 \pm \\
1.2\end{array}$ & $\begin{array}{c}100.81 \pm \\
0.78\end{array}$ & $\begin{array}{c}99.99 \pm 1 \\
.23\end{array}$ & $\begin{array}{c}100.34 \pm \\
0.31\end{array}$ & $\begin{array}{c}100.4 \pm 0 \\
.86\end{array}$ & $\begin{array}{c}102.67 \pm \\
3.2\end{array}$ & $\begin{array}{c}102.13 \pm \\
3.33\end{array}$ & $\begin{array}{c}102.07 \pm \\
2.42\end{array}$ & $\begin{array}{c}100.01 \pm \\
1.12\end{array}$ & $\begin{array}{c}100.4 \pm 1 \\
.02\end{array}$ & $\begin{array}{c}100.26 \pm \\
0.41\end{array}$ & $\begin{array}{c}100.12 \pm \\
0.6\end{array}$ \\
\hline & $5 \mathrm{ppm}$ & $\begin{array}{c}100.19 \pm \\
3.03\end{array}$ & $\begin{array}{c}100.5 \pm 3 \\
.07\end{array}$ & $\begin{array}{c}101.95 \pm \\
2.87\end{array}$ & $\begin{array}{c}100.09 \pm \\
0.87\end{array}$ & $\begin{array}{c}97.7 \pm 2 . \\
83\end{array}$ & $\begin{array}{c}103.91 \pm \\
4.61\end{array}$ & $\begin{array}{c}100.2 \pm 1 \\
.88\end{array}$ & $\begin{array}{c}99.6 \pm 1 . \\
76\end{array}$ & $\begin{array}{c}100.08 \pm \\
0.33\end{array}$ & $\begin{array}{c}99.57 \pm 0 \\
.51\end{array}$ & $\begin{array}{c}101.33 \pm \\
3.17\end{array}$ & $\begin{array}{c}100.79 \pm \\
2.97\end{array}$ & $\begin{array}{c}99.55 \pm 0 \\
.92\end{array}$ & $\begin{array}{c}100.74 \pm \\
2.18\end{array}$ & $\begin{array}{c}100.07 \pm \\
1.83\end{array}$ \\
\hline \multirow{2}{*}{ 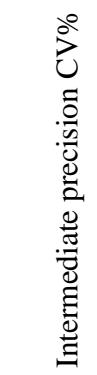 } & Day 2 & 0.015 & 0.014 & 0.012 & 0.025 & 0.01 & 0.024 & 0.017 & 0.015 & 0.041 & 0.022 & 0.004 & 0.02 & 0.016 & 0.003 & 0.014 \\
\hline & Day 3 & 0.006 & 0.015 & 0.008 & 0.012 & 0.008 & 0.012 & 0.003 & 0.009 & 0.031 & 0.033 & 0.024 & 0.011 & 0.01 & 0.004 & 0.006 \\
\hline
\end{tabular}




\section{5- System suitability tests}

264 The fitness of the chromatography system was estimated by a range of system suitability test

265 parameters: Capacity factor (retention factor) $k^{\prime}$, Resolution factor $\left(R_{S}\right)$, number of theoretical

266 plates (Column efficiency) and Asymmetry $\left(A_{s}\right)$, as calculated by the Chromeleon ${ }^{\circledR}$ software.

267 The results of these parameters for each analyte are listed in Table 2. The values of the

268 resolution factor reflect a high-resolution separation of the analytes except for galactose

269 where the $R_{s}$ was only 1.71. In general, all the calculated parameters gave acceptable values;

270 the asymmetry factor was between 0.95 and 1.37 , the capacity factor was more than 2 and the

271 number of theoretical plates was greater than 15000 for all the analysed standards.

\section{6- Results of xylanase treatment of wheat bran}

The oligosaccharides released from wheat bran by endoxylanase treatment were measured and estimated as a percentage of the original wheat bran on a weight basis. Figure 2 shows a chromatogram of the released oligosaccharides from wheat bran after 30 minutes of enzyme treatment.

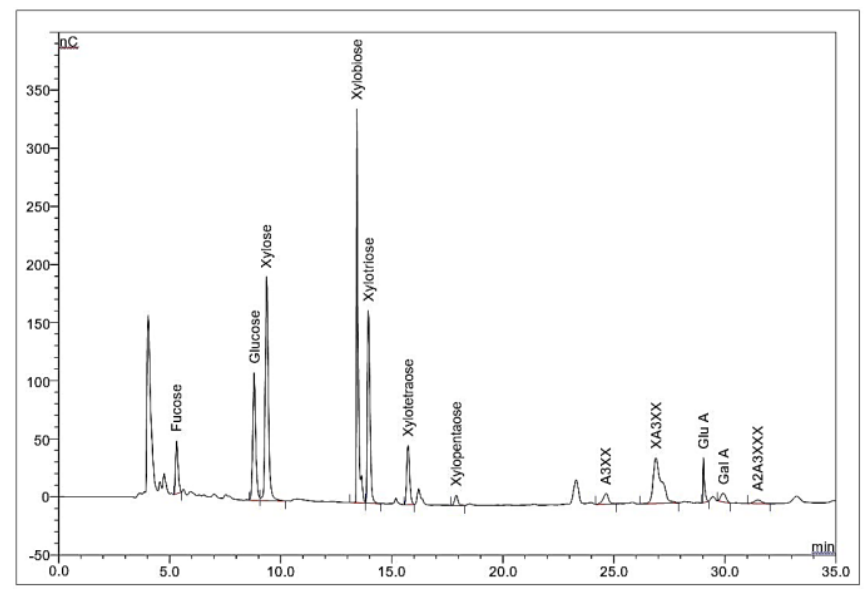

Figure 2 chromatogram of the released mono- and oligosaccharides from wheat bran by xylanase activity using HPAEC-PAD system with Carbopac PA200 column

281 Figure 3 (a) illustrates the evolution of X1-6 over time. Clearly xylose increased over time, xylobiose (X2) also increased monotonically, but by contrast, X3 and X4, after an initial 
283

284

285

286

287

288

289

290

291

292

293

294

295

296

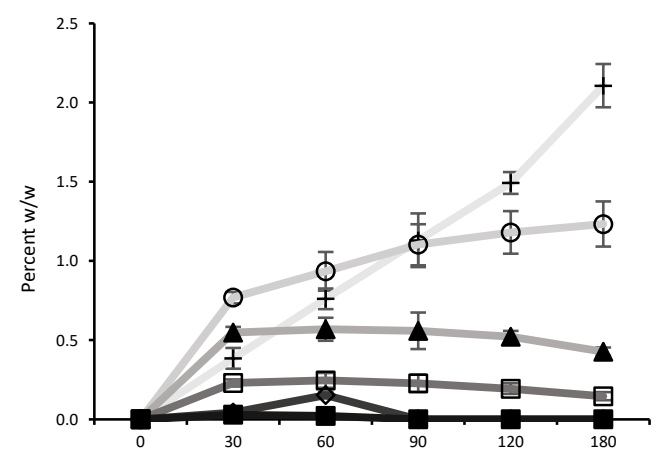

Minutes (a)

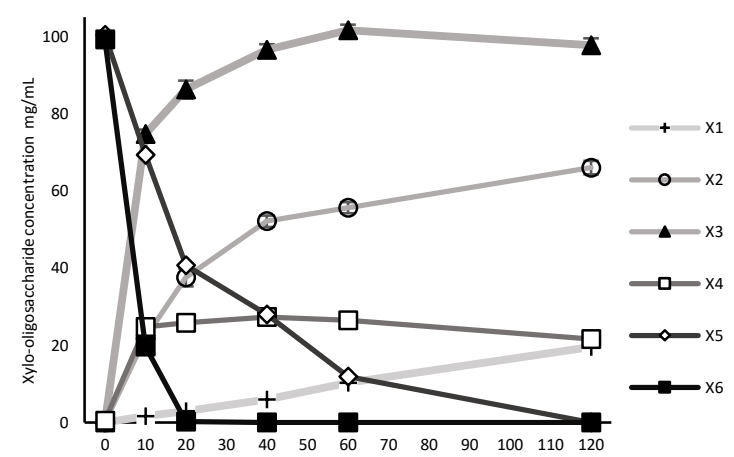

(b) 
299

300

301

302

303

304

305

306

307

308

309

310

311

312

\section{7- Results of enzymatic degradation of XOS standards}

The method was also applied to follow the degradation kinetics of xylo-oligosaccharide standards by the xylanase. Figure 3(b) shows the evolution of X1-X4 following treatment of xylohexaose and xylopentaose (X6 and X5) with endoxylanase. Clearly, the degradation of $\mathrm{X} 6$ is faster than of $\mathrm{X} 5$; the enzyme evidently prefers the larger oligosaccharide. The predominant product is the $\mathrm{X} 3$ followed by $\mathrm{X} 2$, which agrees with the expectation that endoxylanases act within the polysaccharide chain; cleavage of an X6 in the middle would produce two X3s, while cleavage of X5 would produce an X3 and an X2. Significant amounts of X4 were also produced initially from X6 cleavage, with corresponding X2, and with the $\mathrm{X} 4$ then also slowly degrading further to $\mathrm{X} 2$, the enzyme apparently preferring the $\mathrm{X} 4$ as a substrate to the $\mathrm{X} 3$, hence the latter only beginning to degrade, and apparently more slowly, towards the end of the two-hour period. Full understanding of the dynamics underpinning this evolving profile would require detailed population balance modelling based on a more extensive data set. Such understanding would enable the XOS with the greatest prebiotic benefits to be optimised for human or animal nutrition.

The appearance of an increasing amount of xylose monomer (X1) suggests that the enzyme can attack the terminal units of the larger oligos; the degradation of $\mathrm{X} 3$ also supports this, although this is unexpected for this endoxylanase and, as above, may indicate a side activity or, more likely, some contaminating enzyme. A practical application indicated by the evolving profile is that using endoxylanases to produce particular oligos such as $\mathrm{X} 2$ and $\mathrm{X} 3$, which are believed to have the greatest prebiotic value (Gullón et al., 2008; Van Craeyveld et al., 2008) might be enhanced if performed under a separation system such that the produced oligos are immediately removed from the enzyme, in order to avoid further degradation and control the profile of degradation products. 
323 


\section{4- Conclusion}

325 This work presents a novel HPAEC-PAD method for rapid and accurate quantification of 326 cereal monosaccharides, xylo- and arabinoxylo-oligosaccharides and uronic acids. Gradient 327 elution of the mobile phase allowed high-resolution separation of all the analytes, using both 328 PA200 and PA20 CarboPac columns. The method is applicable for characterising xylan329 degrading enzymes and for measuring the production of mono- and oligosaccharides in foods

330 and animal feeds. Application of the method to test endoxylanase activity on wheat bran and 331 XOS standards revealed dynamic evolution of the XOS profile as the enzyme produces and 332 then degrades the oligosaccharides to monosaccharide. The ability to measure the range of 333 mono- and oligosaccharides arising from xylanase activity on cereal feedstocks will enhance 334 the development and exploitation of enzyme products for food and feed products to enhance 335 human and animal health.

\section{Conflict of interest}

337 The authors state not having any conflict of interest in the publication of this article. 


\section{References}

Aachary, A. A., and Prapulla, S. G. (2009). Value addition to corncob: Production and characterization of xylooligosaccharides from alkali pretreated lignin-saccharide complex using Aspergillus oryzae MTCC 5154. Bioresource Technology, 100(2), 991995. https://doi.org/10.1016/j.biortech.2008.06.050

Akpinar, O., Ak, O., Kavas, A., Bakir, U., and Yilmaz, L. (2007). Enzymatic production of xylooligosaccharides from cotton stalks. Journal of Agricultural and Food Chemistry, 55(14), 5544-5551. https://doi.org/10.1021/jf063580d

Akpinar, O., Erdogan, K., Bakir, U., and Yilmaz, L. (2010). Comparison of acid and enzymatic hydrolysis of tobacco stalk xylan for preparation of xylooligosaccharides. LWT - Food Science and Technology, 43(1), 119-125. https://doi.org/10.1016/j.lwt.2009.06.025

Álvarez, C., González, A., Negro, M. J., Ballesteros, I., Oliva, J. M., and Sáez, F. (2017). Optimized use of hemicellulose within a biorefinery for processing high value-added xylooligosaccharides. Industrial Crops and Products, 99, 41-48. https://doi.org/10.1016/j.indcrop.2017.01.034

Alyassin, M. (2019). Arabinoxylan prebiotics co-production within integrated biorefineries (Doctoral dissertation, University of Huddersfield).

Alyassin, M., and G. M. Campbell (2019). Challenges and constraints in analysis of oligosaccharides and other fibre components. Chapter 15 in G. González-Ortiz, M.R. Bedford, K.E. Bach Knudsen, C.M. Courtin and H.L. Classen (Eds.), The value of fibre: Engaging the second brain for animal nutrition (pp. 343-349). Wageningen Academic Publishers.

Antov, M. G., and Đorđević, T. R. (2017). Environmental-friendly technologies for the production of antioxidant xylooligosaccharides from wheat chaff. Food Chemistry, 235, 175-180. https://doi.org/10.1016/j.foodchem.2017.05.058

Arruda, H. S., Pereira, G. A., and Pastore, G. M. (2017). Oligosaccharide profile in Brazilian Cerrado fruit araticum (Annona crassiflora Mart.). LWT - Food Science and Technology, 76, 278-283. https://doi.org/10.1016/j.lwt.2016.05.017

Bian, J., Peng, F., Peng, X. P., Peng, P., Xu, F., and Sun, R. C. (2013). Structural features and 
antioxidant activity of xylooligosaccharides enzymatically produced from sugarcane bagasse. Bioresource Technology, 127, 236-241.

Bian, J., Peng, P., Peng, F., Xiao, X., Xu, F., and Sun, R. C. (2014). Microwave-assisted acid hydrolysis to produce xylooligosaccharides from sugarcane bagasse hemicelluloses. Food Chemistry, 156, 7-13. https://doi.org/10.1016/j.foodchem.2014.01.112

Biliaderis, C. G., Izydorczyk, M. S., Rattan, O., Biliaderis, Izydorczyk, and Rattan. (1995). Effect of arabinoxylans on bread-making quality of wheat flours. Food Chemistry, 53(2), 165-171. https://doi.org/doi.org/10.1016/0308-8146(95)90783-4

Chapla, D., Pandit, P., and Shah, A. (2012). Production of xylooligosaccharides from corncob xylan by fungal xylanase and their utilization by probiotics. Bioresource Technology, 115, 215-221. https://doi.org/10.1016/j.biortech.2011.10.083

Courtin, C., Swennen, K., Verjans, P., and Delcour, J. A. (2009). Heat and pH stability of prebiotic arabinoxylooligosaccharides, xylooligosaccharides and fructooligosaccharides. Food Chemistry, 112(4), 831-837. https://doi.org/10.1016/j.foodchem.2008.06.039

Cui, S., and Brummer, Y. (2005). Understanding Carbohydrate Analysis. In Food Carbohydrates Chemistry, Physical Properties, and Applications (pp. 66-104). https://doi.org/10.1201/9780203485286.ch2

Cürten, C., Anders, N., Juchem, N., Ihling, N., Volkenborn, K., Knapp, A., ... Spiess, A. C. (2018). Fast automated online xylanase activity assay using HPAEC-PAD. Analytical and Bioanalytical Chemistry, 410(1), 57-69. https://doi.org/10.1007/s00216-017-0712-0

Damen, B., Pollet, A., Dornez, E., Broekaert, W. F., Van Haesendonck, I., Trogh, I., ... \& Courtin, C. M. (2012). Xylanase-mediated in situ production of arabinoxylan oligosaccharides with prebiotic potential in whole meal breads and breads enriched with arabinoxylan rich materials. Food Chemistry, 131(1), 111-118

Dionex Corporation. (2004). Product Manual (CARBOPAC PA200 Column). Dionex USA, Document $\quad N \quad$ (Revision 01), 1-41. Retrieved from https://tools.thermofisher.com/content/sfs/manuals/38510-3199201_CP_PA200_V21.pdf

Falck, P., Aronsson, A., Grey, C., Stålbrand, H., Nordberg Karlsson, E., and Adlercreutz, P. (2015). Production of arabinoxylan-oligosaccharide mixtures of varying composition 
from rye bran by a combination of process conditions and type of xylanase. Bioresource Technology, 174, 118-125. https://doi.org/10.1016/j.biortech.2014.09.139

Falck, P., Precha-Atsawanan, S., Grey, C., Immerzeel, P., Staì̌lbrand, H., Adlercreutz, P., and Nordberg Karlsson, E. (2013). Xylooligosaccharides from hardwood and cereal xylans produced by a thermostable xylanase as carbon sources for lactobacillus brevis and bifidobacterium adolescentis. Journal of Agricultural and Food Chemistry, 61(30), 7333-7340. https://doi.org/10.1021/jf401249g

Faryar, R., Linares-Pastén, J. A., Immerzeel, P., Mamo, G., Andersson, M., Stålbrand, H., ... Karlsson, E. N. (2015). Production of prebiotic xylooligosaccharides from alkaline extracted wheat straw using the K80R-variant of a thermostable alkali-tolerant xylanase. Food and Bioproducts Processing, 93, 1-10. https://doi.org/10.1016/j.fbp.2014.11.004

González-Ortiz, G., Gomes, G.A., dos Santos, T.T. and Bedford, M.R. (2019). New strategies influencing gut functionality and animal performance. Chapter 14 in G. González-Ortiz, M.R. Bedford, K.E. Bach Knudsen, C.M. Courtin and H.L. Classen (Eds.), The value of fibre: Engaging the second brain for animal nutrition (pp. 343-349). Wageningen Academic Publishers.

Gowdhaman, D., and Ponnusami, V. (2015). Production and optimization of xylooligosaccharides from corncob by Bacillus aerophilus KGJ2 xylanase and its antioxidant potential. International Journal of Biological Macromolecules, 79, 595-600. https://doi.org/10.1016/j.ijbiomac.2015.05.046

Gullón, P., Moura, P., Esteves, M. P., Girio, F. M., Domínguez, H., and Parajó, J. C. (2008). Assessment on the fermentability of xylooligosaccharides from rice husks by probiotic bacteria. Journal of Agricultural and Food Chemistry, 56(16), 7482-7487. https://doi.org/10.1021/jf800715b

Immerzeel, P., Falck, P., Galbe, M., Adlercreutz, P., Karlsson, E. N., \& Stålbrand, H. (2014). Extraction of water-soluble xylan from wheat bran and utilization of enzymatically produced xylooligosaccharides by Lactobacillus, Bifidobacterium and Weissella spp. $\begin{array}{llll}\text { LWT-Food Science } \quad \text { and } & \text { Technology, } & \text { 56(2), }\end{array}$ https://doi.org/10.1016/j.lwt.2013.12.013

Izydorczyk, M. S., and Dexter, J. E. (2008). Barley $\beta$-glucans and arabinoxylans: Molecular structure, physicochemical properties, and uses in food products-a Review. Food 
Research International, 41(9), 850-868. https://doi.org/10.1016/j.foodres.2008.04.001

Lafond, M., Tauzin, A., Desseaux, V., Bonnin, E., Ajandouz, E. H., and Giardina, T. (2011). GH10 xylanase D from Penicillium funiculosum: Biochemical studies and xylooligosaccharide production. Microbial Cell Factories, 10(1), 20. Li, H., Qing, Q., Kumar, R., and Wyman, C. E. (2013). Chromatographic determination of 1 , 4- $\beta$ xylooligosaccharides of different chain lengths to follow xylan deconstruction in biomass conversion. Journal of Industrial Microbiology and Biotechnology, 40(6), 551559. https://doi.org/10.1007/s10295-013-1254-X

Mathew, S., Karlsson, E. N., and Adlercreutz, P. (2017). Extraction of soluble arabinoxylan from enzymatically pretreated wheat bran and production of short xylo-oligosaccharides and arabinoxylo-oligosaccharides from arabinoxylan by glycoside hydrolase family 10 and 11 endoxylanases. Journal of Biotechnology, 260, 53-61. https://doi.org/10.1016/j.jbiotec.2017.09.006

Nieto-Domínguez, M., de Eugenio, L. I., York-Durán, M. J., Rodríguez-Colinas, B., Plou, F. J., Chenoll, E., ... Jesús Martínez, M. (2017). Prebiotic effect of xylooligosaccharides produced from birchwood xylan by a novel fungal GH11 xylanase. Food Chemistry, 232, 105-113. https://doi.org/10.1016/J.FOODCHEM.2017.03.149

Reddy, S. S., and Krishnan, C. (2016). Production of high-pure xylooligosaccharides from sugarcane bagasse using crude $\beta$-xylosidase-free xylanase of Bacillus subtilis KCX006 and their bifidogenic function. LWT - Food Science and Technology, 65, 237-245. https://doi.org/10.1016/j.lwt.2015.08.013

Rocklin, R. D., and Pohl, C. A. (1983). Determination of carbohydrates by anion exchange chromatography with pulsed amperometric detection. Journal of Liquid Chromatography, 6(9), 1577-1590. https://doi.org/10.1080/01483918308064876

Samanta, A. K., Jayapal, N., Kolte, A. P., Senani, S., Sridhar, M., Dhali, A., ... Prasad, C. S. (2015). Process for enzymatic production of xylooligosaccharides from the xylan of corn cobs. Journal of Food Processing and Preservation, 39(6), 729-736. https://doi.org/10.1111/jfpp.12282

Saulnier, L., Sado, P. E., Branlard, G., Charmet, G., and Guillon, F. (2007). Wheat arabinoxylans: Exploiting variation in amount and composition to develop enhanced varieties. Journal of Cereal Science, 46(3), 261-281. 
461

462

463

464

465

466

467

468

469

470

471

472

473

474

475

476

477

478

479

480

481

482

https://doi.org/10.1016/j.jcs.2007.06.014

Uçkun Kiran, E., Akpinar, O., and Bakir, U. (2013). Improvement of enzymatic xylooligosaccharides production by the co-utilization of xylans from different origins. Food and Bioproducts Processing, 91(4), 565-574. https://doi.org/https://doi.org/10.1016/j.fbp.2012.12.002

Uhrovčík, J. (2014). Strategy for determination of LOD and LOQ values-Some basic aspects. Talanta, 119, 178-180. https://doi.org/10.1016/j.talanta.2013.10.061

Van Craeyveld, V., Swennen, K., Dornez, E., Van de Wiele, T., Marzorati, M., Verstraete, W., .. Courtin, C. M. (2008). Structurally different wheat-derived arabinoxylooligosaccharides have different prebiotic and fermentation properties in rats. The Journal of Nutrition, 138(12), 2348-2355. https://doi.org/10.3945/jn.108.094367

Vinkx, C. J. A., and Delcour, J. A. (1996). Rye (Secale cereale L.) arabinoxylans: a critical review. Journal of Cereal Science, 24(1), 1-14. https://doi.org/10.1006/jcrs.1996.0032

Wan Azelee, N. I., Jahim, J. M., Ismail, A. F., Fuzi, S. F. Z. M., Rahman, R. A., and Md Illias, R. (2016). High xylooligosaccharides (XOS) production from pretreated kenaf stem by enzyme mixture hydrolysis. Industrial Crops and Products, 81, 11-19. https://doi.org/10.1016/j.indcrop.2015.11.038

Wu, H., Li, H., Xue, Y., Luo, G., Gan, L., Liu, J., ... Long, M. (2017). High efficiency coproduction of ferulic acid and xylooligosaccharides from wheat bran by recombinant xylanase and feruloyl esterase. Biochemical Engineering Journal, 120, 41-48. https://doi.org/10.1016/j.bej.2017.01.001

Xue, J. L., Zhao, S., Liang, R. M., Yin, X., Jiang, S. X., Su, L. H., ... Feng, J. X. (2016). A biotechnological process efficiently co-produces two high value-added products, glucose and xylooligosaccharides, from sugarcane bagasse. Bioresource Technology, 204, 130138. https://doi.org/10.1016/j.biortech.2015.12.082

Zhang, H., Xu, Y., and Yu, S. (2017). Co-production of functional xylooligosaccharides and fermentable sugars from corncob with effective acetic acid prehydrolysis. Bioresource Technology, 234, 343-349. https://doi.org/10.1016/j.biortech.2017.02.094 